DIGITAL COMMONS
@ UNIVERSITY OF SOUTH FLORIDA

Volume 4

Issue 1 Volume 4.1 (Spring 2014)

\section{ABO: Interactive Journal for Women in the Arts, 1640-1830}

Article 3

2014

\title{
Charlotte Smith's Beachy Head: Science and the Dual Affliction of Minute Sympathy
}

Kelli M. Holt

Mills College, kellimholtca@gmail.com

Follow this and additional works at: https://digitalcommons.usf.edu/abo

Part of the Feminist, Gender, and Sexuality Studies Commons, and the Literature in English, British Isles Commons

\section{Recommended Citation}

Holt, Kelli M. (2014) "Charlotte Smith's Beachy Head: Science and the Dual Affliction of Minute Sympathy," ABO: Interactive Journal for Women in the Arts, 1640-1830: Vol.4: Iss.1, Article 3.

http://dx.doi.org/10.5038/2157-7129.4.1.2

Available at: https://digitalcommons.usf.edu/abo/vol4/iss1/3

This Scholarship is brought to you for free and open access by Digital Commons @ University of South Florida. It has been accepted for inclusion in ABO: Interactive Journal for Women in the Arts, 1640-1830 by an authorized administrator of Digital Commons @ University of South Florida. For more information, please contact digitalcommons@usf.edu. 


\title{
Charlotte Smith's Beachy Head: Science and the Dual Affliction of Minute Sympathy
}

\author{
Abstract \\ Greatly illustrative of Adam Smith's statement in his Theory of Moral Sentiments that the sympathizer \\ must "adopt the whole case of his companion with all its minutest incidents; and strive to render as \\ perfect as possible that imaginary change of situation upon which his sympathy is founded"--while also \\ complementing notions of feeling from the work of Anna Barbauld--Beachy Head and its minutiae \\ "renders" an utterly sympathetic argument, one void of gender conventions, that comments on nature's \\ inhuman and human condition.

\section{Keywords} \\ Gender Studies, Ecocriticism, Charlotte Smith, Beachy Head, poetry, Romanticism

\section{Creative Commons License} \\ (c) $($ ) $\ominus$ \\ This work is licensed under a Creative Commons Attribution-No Derivative Works 3.0 License.
}


Written at the end of her life and posthumously published in 1807, Charlotte Smith's epic take on the Romantic prospect poem and her homage to the chalky cliffs of Southern England, Beachy Head epitomizes the defiance of genre and gendered expectations that marked Smith's expansive (but often overshadowed) career. Of the poem's little extant scholarship, most tends to unpack the work with a gender critical eye that focuses on its destabilization of a male poetic gaze, while Smith's focus on Beachy Head's precise natural phenomena has inspired critics to position her as one of the first social ecologist poets. ${ }^{i}$ What makes Beachy Head so particularly ripe for these interpretations is Smith's pervasive use of minutiae (a capacious catalog of Beachy Head's ancient history, botany, and zoology) in both the poem's body and footnotes.

While simultaneously showcasing her knowledge of history (natural or otherwise), Smith's poem demonstrates a preoccupation with questions of moral sympathy and its presence in literature; Smith's speaker appears as deeply feeling as she is knowledgeable. While it is impossible to know how familiar Smith was with the sympathetic discourses of the eighteenth century, Beachy Head nonetheless seems to curiously and even radically engage with two of them: Anna Barbauld's 1773 "An Inquiry into Those Kinds of Distress which Excite Agreeable Sensations" and most significantly, Adam Smith's 1759 Theory of Moral Sentiments. I suggest that the crux of this engagement centers upon Beachy Head's uncanny complement to a pivotal claim from Theory in which Adam Smith contends that the sympathizer "must adopt the whole case of his companion with all its minutest incidents; and strive to render as perfect as possible, that imaginary change of situation upon which his sympathy is founded" (I.I.35). This is a demanding call of condition to both author and reader for true "fellow-feeling" (A. Smith I.I.34), as the author's perception of "case" and "rendering" must be impeccable, and the reader's "adoption" "whole" (regardless of the imaginary space on the page in which this adoption may take place). The premier and most curious component of this requirement is "minutest incidents," one that Charlotte Smith seems to challenge herself to take quite literally. In fact, she uses minutiae with such technical care that Beachy Head's unique position as its own (yet inspired) sympathetic treatise seems rather undeniable: the reader does care with near-visceral force about the "perfectly rendered" imaginative space Smith creates; by exhaustively rendering and recreating Beachy Head's classes of life (from the gull to the shepherd), the reader too abandons faux sentimentalism for genuine, precise sympathy, disingenuous gazing for venerating inspection; simply, the poem embodies Adam Smith's "sympathetic" requirements. Thus Smith stresses within her poem the conventionally "feminine" privilege of compassionate feeling (as exemplified by Barbauld's arguments for the gracious acknowledgement of another's distress) while simultaneously stressing the conventionally "masculine" brand of "reasoned" sympathy that Adam Smith advocates. Beachy Head, then, radically defies the confines of explicitly gendered feeling or reason, and thereby anticipates the altruism called for by contemporary ecocriticism.

Adam Smith argues that sympathy is dependent upon "conceiving" another's situation "in a very lively manner..." so that one "can form any conception of what are his sensations" (I.I.1-I.I.2). Charlotte Smith seems to demonstrate these sentiments immediately by creating an ideal "lively" space for such conception, as the poem begins:

On thy stupendous summit, rock sublime, That o'er the channel reared, halfway at sea 
The mariner at early morning hails, I would recline; while Fancy should go forth

And represent the strange and awful hour Of vast concussion when the Omnipotent

Stretched forth the impetuous main flood rush between

The rifled shores, and from the continent

Eternally divided this green isle. (1-10)

Smith introduces the Beachy Head panorama-the English Channel is sprawled before the speaker so that she beckons "Fancy" to explore each "rifled" bit of "shore" — while setting a sweeping, staunchly bold poetic precedent: the Beachy Head locale appears immediately grand ("stupendous," "sublime"), and so does the speaker, for realizing and savoring its greatness. Kari Lokke aptly asserts that this bold vastness is Smith's subversion of "the commanding prospect view... of the social privilege of the male writer." 1 Part of this "prospect view" mimics the vastness of a stage ("rearing" and "stretching" out "halfway at sea"), but unlike many of her preceding male counterparts, Smith does not merely appropriate Beachy Head's summit by reenacting nature as if upon a stage (as demonstrated by her later minutiae). Further, Smith does not maintain this "privileged" view that suggests not only male poet over the general population but male poet over nature, but uses it immediately to establish that the view itself is one to be literally brought down to earth—both in attitude and subject matter.

As Adam Smith requires, this first impression is one full of life. Every facet of the locale and its "companions" are active: the mariner "hails"; the speaker "reclines" yet still imagines "vigorous concussion"; the Omnipotent "stretch[es] forth his arm"; fancy "go[es] forth" and "represents." Even as the rupture causing the "eternally divided...green isle" is only an imagined one, Smith's animated language nonetheless makes the reader feel that breaking tremor. Thus, as Adam Smith argues that the sympathizer, if truly in a situation of sympathy, will "tremble and shudder at the thought of what another feels" (I.I.3), Charlotte Smith uses the imposing physicality of Beachy Head - and its position as a unique ecosystem of living "companions"—-to mimic his conditions from the very start of her poem.

Such priming continues as Smith's sympathetic space is set for additional "lively conception," a space illuminated at both the macro and micro scales. After Smith lingers once more on Beachy Head's panoramic vista by exalting "the dark blue wave / Emerging brilliant rays of arrowy light" and the "glorious sun" "lift[ing]... his resplendent orb," she concentrates her scope (and therefore slyly avoids the mere objectification of nature) by also honing in on "the inmates of the chalky clefts" who fill the air "with shrill harsh cry," seeking their food (14-23). Pointedly, the more the poem progresses, the more evolved Beachy Head's "lively" inhabitants become. As the speaker moves from first describing the lifeless (but still lively) waves and sunshine to the many birds of the cliffs, she privileges neither.

Eventually, Smith closes this stanza by presenting "the lone shepherd and his baying dog" as they "drive to [the] turfy crest" of their "bleating flock" (28-29), spotlighting them as symbols of life, nature and (along with the cliff's other inhabitants) beings deserving sympathetic notice. The shepherd, for instance, is not just a man but also a workman; he is presented not as a

\footnotetext{
"Beachy Head"
} 
creature merely basking in the sun's resplendent orb but as a solitary creature (with his dog, his colleague) who toils through the birds' squalls, his animal's "baying," and "his bleating flock." So while Smith portrays Beachy Head as a sublimely lively, stupendously lovely place, its living creatures aren't obscured from imperfect circumstances that are beyond another's "fellowfeeling." They are still subjected to hard work, annoyance, and desperation. As Donna Landry argues, "Smith's ecology is a form of social ecology, in which human interests figure as intertwined with the interests of the natural world and must be...not pursued in exploitatively instrumental ways" (487). For Smith, Beachy Head (with all its "fellows") acts not as an instrument to be exploited and gawked at for sentimentalism's sake, but as a "lively" companion to be sympathized with and regarded on its own plane of being. In other words, her immediately active language has the effect of encouraging the reader to feel both the breaking tremor that "eternally divided" Britain from the rest of Europe and for the distress (à la Barbauld) of those who inhabit the "green isle" itself.

Just after these opening lines, Smith intensifies her embodiment of Adam Smith's sympathetic conditions with a "case" for abolition, relying on a kind of "minute" intimacy not for gross sentimentality but to present the reality of the slave's individual exploitation. Upon spying Beachy Head's passing ships, Smith's speaker details how much naval "commerce" is built upon slavery and thus how the institution takes its toll on both natural man and nature. Smith situates the reader within the slave's "case," describing:

The beamy adamant and the round pearl

Enchased in rugged covering, which the slave,

With perilous and breathless toil, tears off

From the rough sea-rock deep beneath the waves.

These are the toys of Nature; and her sport

Of little estimate in Reason's eye:

And they who reason, with abhorrence see

Man, for such gauds and baubles, violate

The sacred freedom of his fellow man. (51-59)

While the reader may expect this description of ocean "toil" not to take place in "orient climates" (44) but physically beneath the waves at Beachy Head—within its "lively" station-this location nevertheless acts as an overt parallel location and thereby becomes a part of the poem's sympathetic space. As Smith's speaker presents it, the slave's "case" is physically within the sea, and the reader is seemingly within it too, at eye-level with the forced process of his labor. That the reader is aware of the texture of the rocks and shells_ "rugged" and "rough" - and that the reader is aware of the rhythm of the slave's very breath reinforces his or her placement; the reader is not only witness to the slave's plight, but as close as one's sympathetic "adoption" can apparently be. Therefore, Smith seems to not just "tell" her readers these details, but creates an effect that makes the readers encounter them themselves. Put differently, Smith could merely inform her readers about the slave trade without "rendering" the "minute case" of this particular slave, without rendering what he physically (and emotionally) feels and, by proxy, what the readers feel. Furthermore, such "roughness" and "breathlessness" of the slave's labor contrasts, of course, with what the reader imagines "the beamy adamant" and "round pearl" to feel like and be. Like a nudge into Beachy Head's imaginative waters themselves, those that are deeper, 
colder, and more volatile than the reader may initially imagine, this relatively brief passage still tears away at the "rugged covering" separating the sympathizer's "case" from that of the one deserving sympathy.

But such evocation, does not, as Barbauld denounces in her "Inquiry," tear at this separation for mere (even if well-intentioned) shock alone. The reader does not understand the slave's "extreme of wretchedness" as simply "the author only intend[ing] it to strike horror" (Barbauld 12.223) upon which some typical sentimental writers may depend. The readers imagine his "breathless" toil, but Smith does not appear to gratuitously extend the focus on his "wretched" conditions. Rather, she gives the reader just enough of his "case" to underscore its "reasoned" moral implications. While slaves are not technically Beachy Head's companions (for example, like the lone shepherd upon the cliffs), she makes them so by acknowledging their lack of classed station and their lack of freedom to roam cliffs like those of Beachy Head. Smith calls just enough attention to slavery's violation as people for profit (and to the violation of nature itself for that profit, exemplified by the tearing of the shells) to embody both Adam Smith's and Barbauld's sympathetic requirements.

Smith further positions herself as a particularly sympathetic ecocritic by emphasizing this natureprofit connection at the end of her depiction of this slave's "case." The poem continues:

So the brightest gems

Glancing resplendent on the regal crown,

Are poor and paltry to the lovely light

Of the fair star that, as day declines...the crescent moon

Bathes her bright tresses in the eastern wave. (68-74)

In these lines, Smith orients her reader first upon the diminutiveness of a crown and an ear, and then opens to the vista of nature's majesty. This concluding commentary on the slave trade's ills does not just condemn those who propagate or condone it, but makes them seem foolish-as if these participants are hopelessly chasing after bits of nature that literally pale in comparison to the beauty of nature that is unadulterated and unmanned. Smith suggests then that nature, simply, has no match; nothing is worthy of its destruction, and nothing defends the slave's destruction. Those who condone such malevolence are suggested as being as "poor and paltry" as the "blood" jewels in the royal's crown. Smith's speaker then is not just an observer, voyeur, or selfindulgent poet determined to succumb to overwrought sentimentalism for fancy's sake. She's a "feeling fellow" who "reasons" too, "abhors" rightly and rationally the wrongs of others, and realizes the "regal" bounty of man and nature, especially when this bounty is being pilfered. She expects the same of her readers.

Yet it is after Smith establishes her speaker as wholly sympathetic that she establishes too her method of painstaking minutiae by detailing the locale's ancient but altogether "lively" history. For dozens of lines and with accompanying footnotes that can singularly span four paragraphs, she presents "Contemplation" as "high on her throne of rock" "bid[ing]" history (117-120) to recount the locale's primeval roots:

The period when from Neustria's hostile shore 
The Norman launched his galleys, and the bay...

The new invaders-a proud martial race,

Of Scandinavia the undaunted sons

Whom Dogon, Fier-a-bras, and Humfroi led

To conquest, while Trinancia to their power

Yielded her wheaten garland, and when thou,

Parthenope, within thy fertile bay

Received the victors. (121-131)

This inclusion of Beachy Head's ostensibly ancient (and therefore arguably somewhat irrelevant) history could be read as Smith merely illustrating her learnedness in the truest epic form and as complementing the expansiveness of the "commanding prospect view" that Lokke references. Indeed, such historicism does both subvert and co-opt what was in her time viewed as conventionally "masculine," "serious" study, especially since this particular description is of "hostile" battle and "conquest."

But what complicates this reading is that Smith marks such minutiae of battles and conquests with as much sympathy as density and authority. For instance, Smith describes how wars are fought and won by man in tandem with nature, in spite of nature, or within nature; Smith does not remove the human element from the "hostile" seas shores on which historical "advances" are made, nor does she remove the non-human element from human deeds. She acknowledges that war strategy comes from a feeling being and that war itself affects nature - that war has chiseled away at the Beachy Head locale itself. Simply, within this imaginative textual space, Smith seems interested in not just asserting her "masculine" learnedness either earnestly or pretentiously, but for a more pointed emotional purpose-one that engages with Adam Smith and Barbauld. She seems to strive for "lively" and compassionate recreation of the "cases" of the space's long-dead inhabitants (their toils, their tolls, and their places among the literal and figurative earth) so that her beloved Beachy Head becomes a haunting microcosm of feeling because of its past, present, and future.

Smith then moves her "sympathy as minutiae" focus from Beachy Head's "perfectly rendered," "lively" past to the explicit natural liveliness of Beachy Head's present-day life, presenting this space to the reader as a wholly animate kingdom and she the sympathizing botanist-zoologist. Smith strews her entire poem with scientific nomenclature: coot (a type of crane) is "fulica aterrima" (215); curlew (another common bird) is "charadrius oedicnemus" (232), and there are numerous other similar examples. Yet most of these scientific denominations are dedicated to Beachy Head's abundant flora. In one particularl instance, Smith uses the scientific term "anemóne nemorosa" (364) in lieu of the plant's common name (thimbleweed) and flags it with an especially assertive footnote: "It appears to be settled on late and excellent authorities that this word should not be accented on the second syllable, but on the penultima. I have however ventured the more known accentuation as more generally used, and suiting better the nature of my verse" (Wu 70n). Hence, Smith shifts her focus from Beachy Head's near-infinite "buried" history to the proper accentuation of just one flower's name. ${ }^{\text {ii }}$ But for what reason? John Anderson argues that such shifting reflects Smith's "attract[tion] to the idea of constructing a ruin, of using fragments expressively," seeing these fragmentary "spaces" (botany, history) as Smith's desire to indeed create a "mosaic" imitating her broad and experimental career (547). (A 
ruin that is lively, however-a living ruin.) Judith Pascoe devotes an entire piece to Smith's botanical focus: she convincingly argues that it is one shared by a number of female poets of the time, and is one that defies the idea that scientific interest is solely a male preoccupation and that female interest in the subject is "unfeminine" and even aggressively immodest.

Anderson's mosaic notion certainly seems applicable to Beachy Head in its entirety, and Pascoe's feminist reading of Smith's botanical interest especially informs my "minute sympathy" argument. ${ }^{\text {iii }}$ Yet in light of Adam Smith's thesis that to render sympathy, one must render another's case "with all its minutest incidents," Charlotte Smith's brash and unabashed focus on Beachy Head's flora and fauna once more illustrates not only her intellect, but also her ecocritical sensitivity. Appropriately, after her many lines describing these natural "inhabitants," Smith's speaker denounces those who merely exploit scientific "inquiry" for "the proudest boast" and "vanity" (390), and thus denounces those who consider their field separate from any moral reverberations. She then ends this passage by reminding the scientist to consider others' fight for survival:

While to his daily task the peasant goes

Unheeding such inquiry-with no care

But that the kindly chance of sun and shower

Fit for his toil the earth he cultivates. (395-398)

Smith appears to connect her use of minutiae to the consideration (if not requirement) of sympathy quite directly in these lines, asking both the "vain scientist" and the reader to situate themselves in the place of this peasant and to conclude that scientific interest and sympathy are not mutually exclusive. Furthermore, that this peasant "companion" is "with no care" is especially suggestive: while he is both without care for purposeless scientific inquiry and carefully concerned about the weather's effects on his livelihood (in this "lively" space no less), he is likely without the care from others too-largely without others' sympathy. Smithbotanist, zoologist, and compassionate poet-equates the human with the naturally inhuman throughout these "fragments," but especially emphasizes the kind interdependence between the land and those who tend to it at this fragment's end.

With her readers well-versed in Beachy Head's "minutest incidents" of past and present and hence properly primed for "fellow-feeling," Smith next introduces the first of the poem's two most evocative "companions," "acquaint[ing]" the reader with his "provocation" as well as priming them to "sympathize with [his] fear or resentment" (A. Smith I.I.7). The speaker even gifts her own poetic space to this "lone shepherd" for a time. In his "rhapsody" (576), he laments the loss of his love:

The nightingale will then have ceased

To sing her moonlight serenade

But the gay bird with blushing breast

And woodlarks still will haunt the shade. ... . (625-628)

Of course, this lament plays with the rather common Romantic notion of nature's woodland creatures informing the poetic observer's agony; again, non-human natural companions act in 
tandem and as one with their human counterparts. Yet Smith, leaving no detail unnotedensuring no risk of the reader not feeling utterly "placed" in this lovelorn shepherd's situationnotes in this passage's footnote that the robin's scientific name is "Motacilla rubecula," and the woodlark's "Alauda nemorosa"; she details too the times in which they sing at night (Wu 127n and 128n). So while the lovelorn shepherd is certainly deserving of compassionate feeling alone, the speaker still maintains her employment of cataloging the "sympathetic minute." That is, Smith's notion of creating a "perfectly rendered" space down to the smallest detail does not halt just because she has given over her poetic voice to a more overtly sympathetic (poetic) figure. Smith's speaker's allegiance to perfected minutiae never wavers.

Smith further beckons for the reader's sympathy as this shepherd's rhapsody concludes, not to "half [break] the reader's heart...for his agreeable entertainment" (Barbauld 1.214), but to illustrate that even in one man's "minute" case, fellow-feeling is necessary. The shepherd states:

Ye phantoms of unreal delight, Visions of fond delirium born, Rise not on my deluded sight, Then leave me drooping and forlorn

To know such bliss can never be, Unless Amanda loved like me. (649-654)

Jacqueline Labbe argues that Smith both "celebrates" and "reproaches" this lovelorn shepherd by illustrating "his naïve idealism." I respectfully disagree. While this character's heartsickness could be seen as melodramatic fodder to mock if examined independently from the rest of the piece, when examined in context of the piece itself, this rhapsody appears well-placed within the sympathetic "case" (within the larger sympathetic space) Smith seems so intent on rendering. This "idealism" appears instead to be a rather sincere and pointed example ("minute incident") of the simple need for sympathy. Again, as the reader has been so painstakingly placed in Beachy Head's imaginative space and with sympathy so highlighted throughout the entire work, this shepherd's basic yearning for companionship is a natural progression of Smith's achievement in making the reader a "feeling-fellow." The first person narration alone allows the reader to be in this shepherd's "sympathetic space"; his point of view is the reader's too. Smith's speaker's "passing" the poem over to him is not, as Labbe implies, a patronizing act but a poetically sympathetic one: Smith could have suggested his "naïve idealism" without allowing him this soliloquy.

But Smith doesn't merely give this shepherd a poetic voice but a hopeful end, acting not only as another sympathetic gift to the shepherd but to the reader as well. "Some future blessings he may yet enjoy" (658), the speaker states, while "as above him sail the silver clouds" (659) and:

He follows them in the thought to distant climes

Where, far from the cold policy of this, Dividing him from her he fondly loves, He in some island of the southern sea May haply build his cane-constructed bower... With long green foliage rippling in the gale. (660-666) 
This promise of "some future blessing" suggests to the reader a promise that his or her sympathy is not in vain - and argues too that even outside of fancy, sympathy does not have to accompany a sense of foreboding. The speaker then concludes, "For what is life, when Hope has ceased to strew / Her fragile flowers along its thorny way? And sad and gloomy are his days who lives / Of Hope abandoned!" (668-671). Ultimately, these are the words of a sympathetic speaker engaged with the reader in a sympathetic exchange, in tune and in tandem with nature. (These "fragile flowers" of "Hope" are humanity and nature interlocked once more.)

This hope is ostensibly abandoned by Smith with her presentation of the poem's final character, the lone hermit, however: his "case" is seemingly one not only plagued by an insurmountable sense of tragedy, but meant to plague the sympathetic impulses of any "attentive spectator" (A. Smith I.I.4). As the readers are progressively situated in the "lively" space of Beachy Head so that they are most susceptible to "fellow-feeling" for all of its living creatures and components, Smith's closing hermit is the capstone of her sympathetic thesis-a sympathetic wallop to crown her steady gradation of both minutiae and her stress of compassionate imagination. The poem's last three stanzas detail this hermit, and Smith positions him first (and thus the reader also) "Just beneath the rock / Where Beachy overpeers the Channel wave / Within a cavern mined by wintry tides" (672-674). It is telling that this lone hermit actually lives within Beachy Head-within nature, beyond the bounds of mere visitation that would only ensure a "gazing" void of truly natural sympathy and appreciation. Smith's speaker laments his distress, stating that within this space:

Dwelt one who, long disgusted with the world

And all its ways, appears to suffer life

Rather than live; the soul-reviving gale

Fanning the beanfield or the thyme heath

Had not for many summers breathed on him. (675-679)

Smith draws a distinction with this final change of "case": while the lovelorn shepherd is still allowed the possibility of the hopeful "gale" to move him (666), for this hermit of the rocks, restoration is seemingly long past. Thus, while the reader's "fellow-feeling" for the lovelorn shepherd is assuaged by some degree of future promise, the reader's feeling for this "companion" is primed to be more acute, most minute.

The hermit's pain itself is more acute, as is seemingly the reader's. This figure is "long disgusted" and suffers a kind of living death in a permanent winter-every aspect of his being is harshly depicted. But instead of dismissing or denouncing him as hardened and bitter, Smith paints him as deserving of the highest sympathetic regard, as she explicitly contends that his heart still

Was feelingly alive to all that breathed; And outraged as he was, in sanguine youth, By human crimes, he still acutely felt For human misery. (688-692) 
Smith seems acutely aware herself that this hermit - her embodiment of sympathy-cannot be so if he is indeed bitter or even merely lovelorn. Instead, his command of "fellow-feeling" is so undaunted by "rage" that he is essentially a perfectly rendered, "feelingly alive" savior. Simply, Smith, after all of her apparent labor in recreating Beachy Head's imaginative space, does not rely on subtlety or (contrastingly) overabundant historical or botanical minutiae for her portrayal of this final character; her minutiae is merely embodied by this single being. While she, of course, situates her readers within the "cases" of single beings throughout the poem, this hermit is set apart from the others: Smith gives her full attention to this hermit (and so the reader does) at the end of her piece for a sustained period of space, not appearing to privilege his "case" over the slave's, the lovelorn shepherd's, or even that of a blade of mustard grass, but instead to encapsulate all of their elements of suffering by the hermit alone. That this hermit is perfectly aware of "human crimes" makes him the perfect embodiment of all of Beachy Head's "companions."

The "savior"-hermit's death at the end of the poem then seems inevitable, and it is with his death that Smith mimics sending her readers over a kind of sympathetic edge (nearly over the carefully recreated cliffs of Beachy Head itself), and by doing so, Smith seems to give a final nod to Adam Smith's sentiments of situating oneself completely within another's suffering. Interestingly, Lokke describes Smith's shift in view to sea level itself (at the hermit's cave) as a "movement [that] replicates the 'headlong fall' (685) of the hapless sheep who lose their footing as they graze on the brink of the summit... an end that dramatically (and perhaps ironically) refuses any sublime prospect or transcendent elevation." This notion of "falling" from the summit seems especially apt when considering Smith's sympathetic suggestions, as the reader's emotions are primed to crest at the hermit's literal decline. This decline hits quickly—an "angry flood" assaults the rocky shores adjacent to the hermit's cave (722) and the hermit is swallowed by the waters of Beachy Head. Yet it is his presence post mortem that inspires the appearance and sympathy of his "fellows":

At daybreak, anxious for the lonely man, His cave the mountain shepherds visited, Though sand and banks of weeds had choked their way: He was not in it, but his drowned corse, By the waves wafted, near his former home Received the rites of burial. (23-28)

In juxtaposition, this death scene seems stunningly complementary to the following from Adam Smith:

We sympathize even with the dead...It is miserable, we think, to be deprived of the light of the sun; to be shut out from life and conversation; to be laid in the cold grave. The tribute of our fellow-feeling seems doubly due to them now, when they are in danger of being forgot by every body; and, by the vain honours which we pay to their memory, we endeavour, for our own misery, artificially to keep alive our melancholy remembrance of their misfortune. (I.I.13)

Smith indeed gives her hermit the death of a dark, cold grave, and dooms him even before death 
from most life and conversation. (And that the hermit's burial place is quite literally one with Beachy Head - that he is seemingly swallowed up by it — culminates Smith's concept of [nonhuman] nature and humanity being one.) Unlike the lovelorn shepherd, he has not even a lamentation, or, more specifically, a former lover to lament. This hermit is the ultimate martyr, his death the ultimate misery, and his legacy the ultimate instigator of "fellow-feeling."

However, Charlotte Smith does not completely saddle this figure with notions of misery and hopelessness only, but evokes Adam Smith's notion of "doubly due" tribute as the mountain shepherds grant him funeral rites, especially poignant since the hermit is noted just before his death as bestowing similar rites for drowned seamen. ("Where the dank sea-wrack marked the utmost tide, / And with his prayers performed the obsequies / For the poor helpless stranger" [715-718].) Whether the kindness afforded to this final "poor helpless stranger" is merely a "vain honour" "endeavored" to nullify personal grief is not expressly stated in these last lines, yet Smith does note the shepherds' motivating "anxiety," and suggests too then, at least in part, that this morbid blessing was to give peace to both sympathizing shepherd and sympathizing hermit - that sympathy, if anything - is a dual affliction. As both Smiths imply, compassion for the dead's "misfortune" is not only an act of homage but also an act of mitigating the living's mourning of the dead.

As Beachy Head's speaker sympathetically gives over her poem for a time to the lovelorn shepherd, she also performs this poetically sympathetic act for the final hermit - not merely by focusing the poem's final lines on him exclusively or quoting a once-spoken soliloquy by the man-but by giving her authorship over to him (again, now one with nature) in this "lively" sympathetic space. Thus, Smith's sympathetic argument peaks at this exchange of poetic power, and this exchange is predicated upon the discovery of Beachy Head (or some semblance thereof-“these lines") within his cave:

Those who read,

Chiseled within the rock these mournful lines,

Memorials of his sufferings, did not grieve

That, dying in the cause of charity,

His spirit, from its earthly bondage freed,

Had to some better region fled for ever. (726-731)

It should be noted first that some critics deny that this is where Smith intended to end Beachy Head, but as Lokke cites in her piece, this conclusion - and its eventual "fallen prospect view"is so consistent with the rest of the piece (in subject matter, progression, and style) that it seems deliberate. ${ }^{\text {iv }}$ Nevertheless, the ultimate sympathetic might of Beachy Head rests with a seemingly epic last bit of minutiae: scribbled lines upon a rock, in a deep, dark cave, no doubt already worn by water. That the reader is not privy to exactly what these lines are is perhaps the most provocative point of the poem's end. (Are they literal? A few words of the hermit's life? A bit of Beachy Head to be completed by Smith's speaker?) Certainly, the reader can only speculate why Smith doesn't make these lines precisely "legible," yet this illegibility seems especially apt considering Beachy Head's overarching sympathetic symbolism: Smith's speaker could very well be "gifting" the final piece of the poem's power to the readers themselves, allowing them to "render" sympathetically and reasonably the hermit's legacy on their own, giving him even more 
of an artistic life after death.

"I may still find some entertainment in your conversation," Adam Smith concludes in his own work of sympathy, but "if you have...no fellow-feeling for the misfortunes I have met with...We can no longer converse upon these subjects" (I.I.34). For Charlotte Smith too, such "fellowfeeling for the misfortunes" of others- "perfectly rendered" with the most "minutest incidents" of Beachy Head's companions (male or female, human or non-human) - is a condition for any sympathetic engagement in which a creature bears the conditions of another. She illustrates throughout this epic the epically viable desire to sympathize with all others, and to experience all others as sympathetic too. By doing so, she redefines the poet as entirely equal to his or her subject.

\section{Endnotes}

${ }^{1}$ See Donna Landry's thoughtful and thought-provoking essay titled "Green Languages? Women Poets as Naturalists in 1653 and 1807" for a purely ecocritical examination of "Beachy Head".

${ }^{2}$ As Judith Pascoe notes also in her essay on Charlotte Smith, later mentioned.

${ }^{3}$ Pascoe connects Smith's minutiae to Darwin's, stating, "But it is Darwin's very 'minuteness,' his holding a magnifying glass to the tiniest facets of the natural world, that acted as a force of liberation for Charlotte Smith. The wood sorrel that Charlotte Smith describes as having 'light thin leaves, / Heart-shaped, and triply folded' (231) is representative of a school of Darwininspired botanical writing intent on fashioning a world in which the forest is less important than the trees, or rather, that the lacework of veins on one particular leaf" (n.pag.). Pascoe suggests that this "force of liberation epitomizes Smith's desire to embrace science and poetry as one, although Pascoe's focus is not on this "oneness" being expressly sympathetic.

${ }^{4}$ Therefore, Lokke sides with Smith scholar (and author of a 14-volume series on her work) Stuart Curran.

\section{Works Cited}

Anderson, John M. "“Beachy Head”: The Romantic Fragment Poem as Mosaic." Huntington Library Quarterly 63.4 (2000): 547-74. Rpt. in Poetry Criticism. Ed. Michelle Lee. Vol. 104. Detroit: Gale, 2010. Literature Resource Center. Web. 16 Apr. 2012.

Barbauld, Anna. "An Inquiry into Those Kinds of Distress which Excite Agreeable Sensations." 1773. Poetess Archive. Web. 13 Mar. 2012.

Labbe, Jacqueline M. "Locating the Poet in "Beachy Head"." Charlotte Smith: Romanticism, Poetry and the Culture of Gender. Manchester, England: Manchester UP, 2003. 42-65. Rpt. in Poetry Criticism. Ed. Michelle Lee. Vol. 104. Detroit: Gale, 2010. Literature Resource Center. Web. 16 Apr. 2012. 
Landry, Donna. "Green Languages? Women Poets as Naturalists in 1653 and 1807." Huntington Library Quarterly, Forging Connections: Women's Poetry from the Renaissance to Romanticism 63.4 (2000). 467-89. Web. 1 Mar. 2013.

Lokke, Kari. "The Figure of the Hermit in Charlotte Smith's "Beachy Head"." Wordsworth Circle 39.1-2 (2008): 38+. Literature Resource Center. Web. 16 Apr. 2012.

Pascoe, Judith. "Female Botanists and the Poetry of Charlotte Smith." Re-Visioning Romanticism: British Women Writers, 1776-1837. Ed. Carol Shiner Wilson and Joel Haefner. Philadelphia: U of Pennsylvania P, 1994. 193-209. Rpt. in Poetry Criticism. Ed. Michelle Lee. Vol. 104. Detroit: Gale, 2010. Literature Resource Center. Web. 12 Apr. 2012.

Smith, Adam. The Theory of Moral Sentiments. 1790. Library of Economics and Liberty. Web. 14 Apr. 2012.

Smith, Charlotte. "Beachy Head.” Romanticism. Ed. Duncan Wu. Oxford: Blackwell, 2006. 12241. Print. 